MATEC Web of Conferences 19, 01034 (2014)

DOI: $10.1051 /$ matecconf/ 20141901034

(C) Owned by the authors, published by EDP Sciences, 2014

\title{
Mathematical Simulation of Heat Impact of Heated Up to High Temperatures Particle on Human Skin: Simple One- Dimensional Statement
}

\author{
Andrey S. Solodkin ${ }^{\mathrm{a}}$ and Konstantin O. Ponomarev \\ ${ }^{1}$ National Research Tomsk Polytechnic University, 634050, Tomsk, Russia
}

\begin{abstract}
It is developed physical and mathematical models of process of a heat transfer between skin and a heating source - single heated up to high temperatures particle. Temperature distribution in system "particle-skin" for heated wooden particle is obtained. The data obtained during work can be used for addition of already available materials on the given subjects and comparisons of influences on a skin of various factors, and also can be useful to development of new systems of protection against the influences damaging factors in the conditions of fire.
\end{abstract}

\section{Introduction}

The problem of forest fires became especially actual last decade [1]. Catastrophic forest fire occur in the various states of our planet. It is enough to note events of 2009 to Australia or fires of 2010 in the Central Russia. As a result of activity of forest fires there is a destruction of forest fund and pollution of atmosphere by products of burning of forest fuels [2]. Besides, forest fires influence the person [3]. Formation of burns on a skin of the person probably as a result of action of thermal radiation from forest fires [4]. To this direction of researches the special attention is paid [5]. Questions of development materials for clothes of forest firemen [6] are especially intensively investigated. However, radiation is only one of mechanisms of transfer of heat of the burning centre to skin of the person [7]. Often enough from forest fire front are taken out heated up to high temperatures particles [8] which can contact to skin of the person. It is necessary to notice, that generally the problem of an estimation of influence of heated up to high temperatures particles on the bared skin of the person is not solved. Such particles can from a different material, and also have the various form and structure. For example, there can be metal, carbonaceous, ceramic or polymeric particles. However in the present research we will be limited only to carbonaceous particles which correspond to the natural scenario, namely to forest fire. It is especially interesting to investigate influence of particles of the small size as they can be formed at forest fires in a considerable quantity. The aim of paper is development of mathematical model and numerical research of heat transfer processes at influence of heated up to high temperatures particle on not protected skin of the person. With a view of understanding of the basic laws it is offered to develop one-dimensional mathematical statement. It is offered to use one-layered skin structure with effective thermophysical properties of human skin. This model is a base for development more advanced mathematical models in future period.

${ }^{\text {a }}$ Corresponding author : andsolodkin@mail.ru

This is an Open Access article distributed under the terms of the Creative Commons Attribution License 4.0, which permits unrestricted use, distribution, and reproduction in any medium, provided the original work is properly cited. 


\section{Physical and Mathematical Statement}

Usually skin subdivides into two types - thick and thin, that is connecting, mainly, with various thickness of epidermis. The thick skin covers palms and soles. For it presence thick epidermis on which external surface especially powerful keratin layer settles down is characteristic.

The skin has rather difficult structure having the features in various parts of a body. The skin consists of three layers: epidermis, derma and hypoderm [9].

Epidermis consists basically of dead cages which operate as a protective barrier against moisture, ultra-violet radiation and heats [5]. Sweat glands pass through epidermis. The bottom layer of epidermis is basal. This layer lays on basal membrane dividing epidermis and derma. Derma is the basic part of a skin. It much more thickly also comprises blood vessels, the nervous endings, sebaceous glands and roots of hair. Epidermis and derma, together taken, have a thickness about $1-2 \mathrm{~mm}$. The hypodermic fabric lays below these two layers which contains sweat glands and large blood vessels which give the chance to a skin to adapt to local heating or cooling, but only in certain limits [10].

At a thermal trauma initially there is a damage of cages that is expressed in skin of their structure and functions. Barrier function of cellular and endocellular membranes is broken, and also ionic pumps are switched off. It, in turn, is accompanied by infringement of distribution of substances in a cage and between a cage and environment, disorganisation of an endocellular metabolism and infringement of system of energy supply [11]. The burn trauma causes heavy metabolic frustration, breaks work of all links of system of delivery of oxygen, including decrease in warm emission, reduction of the maintenance of oxygen in arterial blood and infringement of its recycling [11]. At weak thermal influence will be damaged only epidermis on depth of $1 \mathrm{~mm}$. More intensive thermal impact can lead to defeat not only epidermis, but also derma, and heat impact still more intensity will influence and a hypodermic [9].

For understanding of the basic laws of heat transfer we will consider influence process of heated up to high temperatures particles on skin taking into account following assumptions:

1) One-dimensional model where the particle is as a first approximation considered by a plate of final thickness is considered. Competency of use of such assumption has been proved at research of processes of influence by heated up to high temperatures particles on forest fuels.

2) Carbonaceous particles are considered. It corresponds to the scenario of natural fire danger. It is supposed, that such particles are formed as a result of wood and forest fuels thermal destruction. Heated up to high temperatures particles are taken out from front of forest fire as a result of action of convective columns (plume).

3) The single-layered system of human skin structure with effective thermophysical characteristics is considered.

4) It is supposed, that thermophysical properties of particle and human skin does not depend on temperature.

5) Destruction of skin tissues under the influence of the high temperatures is neglected.

6) Evaporation of cellular moisture from skin tissues also is neglected.

7) Conduction is a basic mechanism of heat transfer in human skin.

8) Monolithic structure of human skin is considered.

Decision area is described on Fig. 1. 


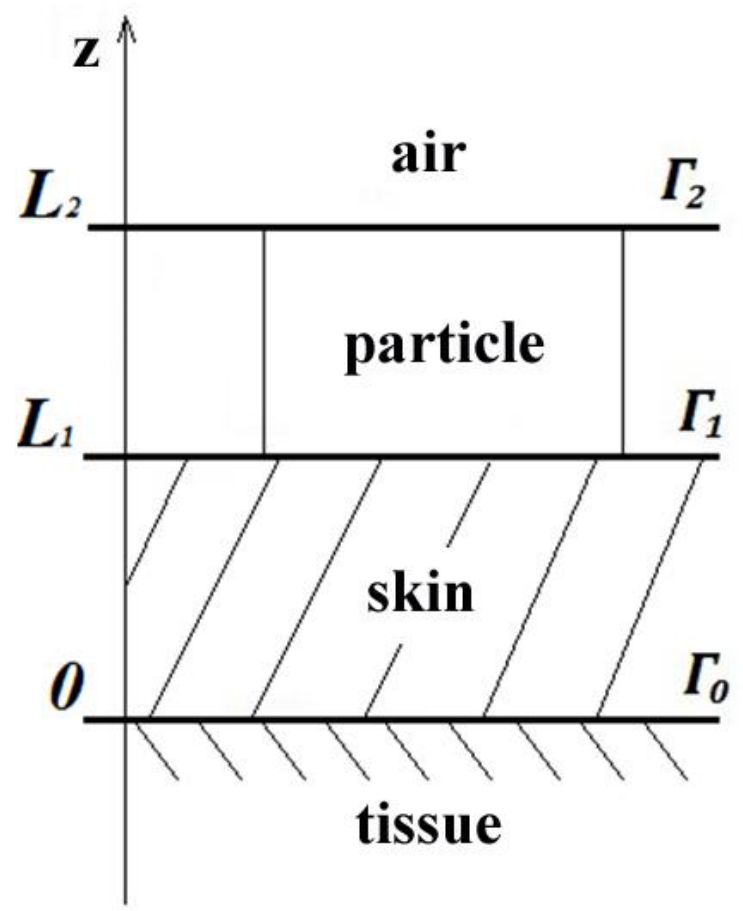

Figure 1. The scheme of decision area

Heat transfer process in considered system is described mathematically by system of the nonstationary partial differential equations with corresponding boundary and initial conditions:

$$
\begin{aligned}
& \rho_{1} c_{1} \frac{\partial T_{1}}{\partial t}=\lambda_{1} \frac{\partial^{2} T_{1}}{\partial z^{2}}, 0<z<L_{1}, \\
& \rho_{2} c_{2} \frac{\partial T_{2}}{\partial t}=\lambda_{2} \frac{\partial^{2} T_{2}}{\partial z^{2}}, \quad L_{1}<z<L_{2},
\end{aligned}
$$

Initial conditions can be written down as follows:

$\mathrm{t}=0: \mathrm{T}_{1}=\mathrm{T}_{1}^{0}$,

$\mathrm{t}=0: \mathrm{T}_{2}=\mathrm{T}_{2}^{0}$,

Boundary conditions:

$$
\begin{aligned}
& \mathrm{z}=0: \lambda_{1} \frac{\partial T_{1}}{\partial z}=\alpha_{1}\left(T-T_{t s}\right), t>0, \alpha_{1}>0 \\
& \mathrm{z}=\mathrm{L}_{1}: \lambda_{1} \frac{\partial T_{1}}{\partial z}=\lambda_{2} \frac{\partial T_{2}}{\partial z}, t>0, T_{1}\left(t, L_{1}\right)=T_{2}\left(t, L_{1}\right) \\
& \mathrm{z}=\mathrm{L}_{2}: \lambda_{1} \frac{\partial T_{2}}{\partial z}=\alpha_{2}\left(T_{e}-T\right), t>0, \alpha_{2}>0
\end{aligned}
$$


Where $T_{i}, \rho_{i}, c_{i}, \lambda_{i}$ - temperature, density, heat capacity and heat conductivity ( $i=1-$ heated up to high temperatures particle, $i=2$ - human skin), $\alpha_{1}$ and $\alpha_{2}$ - heat transfer factors, $t$ - time, $z$ - coordinate. Indexes $e$ and $t s$ corresponds to environment and under skin tissue. Index 0 corresponds to parameters at initial time.

For the decision of the formulated system of the equations the finite difference method by Samarskiy [12] was used. Difference analogues of the one-dimensional differential equations are solved by marching method [12].

\section{Results and Discussion}

Numerical realization of mathematical model is carried out in language of high level Object Pascal. For computing experiments the computer of type IBM PC with DualCore Intel Pentium $3 \mathrm{GHz}$ processor unit and operative memory about $8 \mathrm{~GB}$ was used. The one-dimensional mathematical model allows to develop resource effective algorithm for program realization. Process of heat transfer calculation occurs in a mode advancing real time of development of process. It is allows to write, that the given mathematical model has prospects for use in modern medical information systems $[13,14]$.

Temperature distribution in system of particle-skin for various initial temperatures of heated up to high temperatures particles is presented on Fig. 2. Short-term influence of particles on skin was accepted in the present work. This assumption corresponds to the scenario of behaviour of the person which has no traumas obtained as a result of a fire and is capable to exclude long influence of heated particles on skin. The analysis of the curves presented on Fig. 2 allows to drawn a conclusion: the particle intensively cools down as a result of environment and heat removal influence in skin layers of the person. Logical the conclusion serves that fact, that hotter particles represent the more danger to the person. Such particles have bigger stock of heat and are capable to cause more harm to tissues of human skin. The analysis of temperature distributions shows, that at any temperatures enough a hot particle appreciable influence is observed in the top millimetric skin layer. It is necessary to notice, that is necessary to study in more details heat transfer at rather not high and average temperatures of particles as in the course of the movement in the air environment they also cool down. Development of certain scenarios of influence of heated particles on human skin and marking of so-called hot, moderately hot and cold particles is possible in future period.

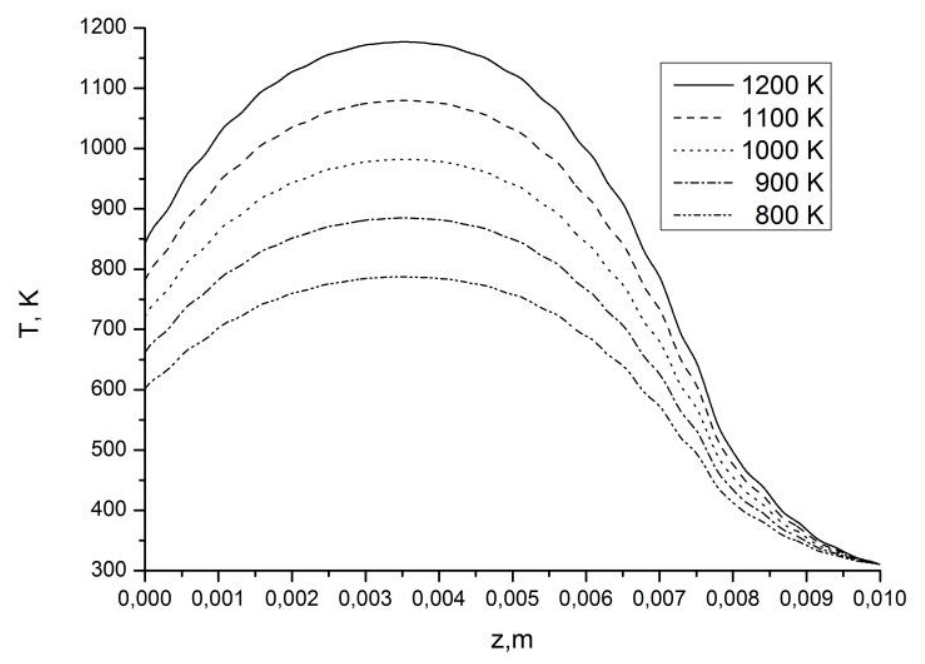

Figure 2. Temperature distribution in system of heated particle - human skin for different initial particle temperature (particle impact times is 10 seconds) 
Dependence of skin temperature in the deeper layer from influence time is presented on Fig. 3. Also particles with various initial temperatures are considered. Various distribution of temperature for particles with different initial temperature is natural. The analysis of the presented curves allows to draw conclusion, that during first second from the moment of contact of a particle and skin its temperature in the deeper layer of skin practically does not vary. The next second the temperature grows practically equally for particles with various initial temperature. There is the most intensive heating of inside skin layers in time from 2 seconds till 5-6 seconds. Then warming up also amplifies, but its rate slightly decreases.

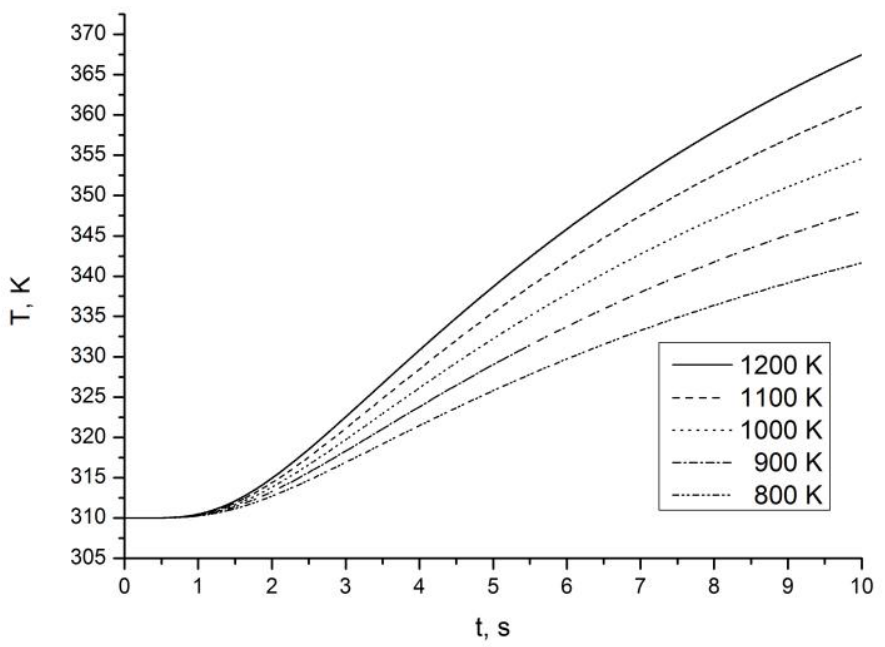

Figure 3. Temperature in depth of skin layer depend on time of influence for different initial temperature of heated particle (time of impact is 10 seconds)

Thus, simplified mathematical model of thermal influence of heated up to high temperatures particle on human skin is developed. Heat transfer research in skin layer at influence of heated up to high temperatures carbonaceous particle is carried out in the view of the basic laws. As it has been told above, development of such model opens prospects of creation of new generation of medical information systems on the basis of the deterministic mathematical models. Development of the complex deterministic-probabilistic approach with attraction of forest fire danger prognostic modeling results [15-17] is possible.

\section{Conclusion}

It is developed physical and mathematical models of heat transfer process between human skin and a heating source - single heated up to high temperatures particle. Temperature distribution in system "particle-skin" for carbonaceous particle is obtained.

The data obtained during work can be used for addition of already available materials on the given subjects and comparisons of influences on a skin of various factors, and also can be useful to design new systems of protection against the influences of high temperatures in the conditions of a fire.

The present work plays the important role for development of new medical information systems for structures of the Ministry of Emergency Measures, and also medical institutions and the enterprises of the industry [18]. 


\section{References}

1. G.V. Kuznetsov, N.V. Baranovskiy, Prognoz vozniknoveniya lesnikh pozharov $i$ ikh ekologicheskikh posledstviy, (2009) (In Russian)

2. D.M.J.S. Bowman, J.H. Johnston, Ecohealth, 2, 76 (2005)

3. R.Sh. Enaleev, A.M. Zakirov, J.S. Chistov, E.Sh. Telyakov, Vestnik Kazanskogo tekhnologicheskogo universiteta, 15, 50 (2012) (In Russian)

4. E.N. Valendik, I.V. Kosov, Sibirskiy ecologicheskiy zhurnal, 4, 517 (2008) (In Russian)

5. A. Hummel, K. Lyons, Fire Technology, 50, 1285 (2014)

6. ASTM Standard D 4108-87, Standard test method for thermal protective performance of material for clothing by open flame method, American society for testing and materials (1994)

7. A.E. Pushkareva, Lazerniy selektivniy nagrev elementov kozhi. Diss. Cand. Tech. Sci. (2006) (In Russian)

8. V.V. Terebnev, N.S. Artemiev, A.V. Podgrushniy, Protivopozharnaya zashchita I tushenie pozharov. Kniga 5. Lesa, torphyaniki. Lesosklady (2007) (In Russian)

9. F. Xu, T.J. Lu, K.A. Seffen, Acta Mechanica Sinica, 24, 1 (2008)

10. B.A. Paramonov, Ya.O. Porembskiy, V.G. Yablonskiy, Ozhogi : Rukovodstvo dlya vrachey (2000) (In Russian)

11. M.V. Vildieva, Obosnovanie primeneniya meksidapta $v$ kompleksnom lechenii bolnikh $s$ termicheskoy travmoy, Diss. Cand. Med. Sci. (2009) (In Russian)

12. A.A. Samarskiy, P.N. Vabishchevich, Additivnie skhemy dlya zadach matematicheskoy fiziki (2001) (In Russian)

13. S. Petter, A. Fruhling, International journal of medical informatics, 80, 480 (2011)

14. N. Bricon-Souf, C. Verdier, A. Flory, M.C. Jaulent, IRBM, 34, 9 (2013)

15. A.M. Grishin, N.V. Baranovskij, Journal of Engineering Physics and Thermophysics, 76, 166 (2003)

16. G.V. Kuznetsov, N.V. Baranovskiy, EPJ Web of Conferences, 76 (01028), 1 (2014)

17. G.V. Kuznetsov, N.V. Baranovskiy, Proceedings of SPIE, 8890, paper 889011 (2013) doi: $10.1117 / 12.2033929$

18. D.V. Korobkina, N.V. Baranovskiy, Cloud of Science, 1, 292 (2014) (In Russian) 